УДК 552.11

\title{
ГЕНЕЗИС МАГМ С ПОЗИЦИИ ГОРЯЧЕЙ ГЕТЕРОГЕННОЙ АККРЕЦИИ ЗЕМЛИ
}

\author{
Шкодзинский В. С. \\ ФГБУН Институт геологии алмаза и благородных металлов СО РАН, г. Якутск \\ E-mail: shkodzinskiy@diamond.ysn.ru
}

\begin{abstract}
Полученные многочисленные доказательства горячей гетерогенной аккреции Земли приводят к принципиально новому решению проблемы генезиса магм. По этим данным при аккреции силикатной мантии возник глобальный магматический океан под влиянием импактного тепловыделения. Его придонная часть кристаллизовалась и фракционировала в результате роста давления образующихся верхних частей. Кумулаты формировали ультраосновную мантию, остаточные расплавы - магматический океан. Увеличение температуры и глубины океана обусловили эволюцию придонных остаточных расплавов от кислых до ультраосновных, возникновение соответствующих слоев в океане и обратного геотермического градиента в мантии. В результате остывания и кристаллизации океана сверху вниз 3.8 млрд лет назад образовались раннедокембрийские кристаллические комплексы, кислая кора и литосфера древних платформ. Отделение остаточных расплавов обусловило эволюцию магматизма от кислого до щелочно-ультраосновного и кимберлитового. Прогрев мантии высокотемпературным ядром привел к возникновению в конце протерозоя прямого геотермического градиента, конвекции в мантии и современных геодинамических обстановок, в которых магмы формируются путем фрикционного и декомпрессионного переплавления дифференциатов магматического океана.
\end{abstract}

Ключевые слова: происхождение магм, магматический океан, фрикционное и декомпрессионное плавление.

DOI: 10.34078/1814-0998-2021-2-41-49

\section{ВВЕДЕНИЕ}

Глобальные генетические представления петрологии неразрывно связаны со взглядами на происхождение Земли. С середины прошлого столетия гипотеза холодной гомогенной аккреции Земли, разработанная математиком О. Ю. Шмидтом (1962), является господствующей. Согласно этой гипотезе, Земля формировалась в течение более миллиарда лет в результате одновременного объединения железных и силикатных частиц космического газово-пылевого облака, захваченного гравитационным полем Солнца. Ядро и мантия возникли в результате гравитационного разделения железных и силикатных частиц в земных недрах, кислая кора и раннедокембрийские кристаллические комплексы - результат отделения выплавок из глубинных пород. Магмы образовались путем отделения расплавов из слабо подплавленных пород.

За десятки лет господства этих представлений не было получено ни одного геологического доказательства их справедливости. Наоборот, к настоящему времени установлено большое ко-

(C) Шкодзинский В. С., 2021 личество свидетельств их ошибочности. Расчеты показали, что импактное тепловыделение было способно разогреть вещество Земли на $34000{ }^{\circ} \mathrm{C}$ (Рингвуд, 1982), что свидетельствует об ее горячей аккреции. Это же подтверждается присутствием трендов магматического фракционирования в мантийных ксенолитах и раннедокембрийских кристаллических комплексах, уменьшением изотопного возраста и температуры образования различных пород в полном соответствии с последовательностью формирования при фракционировании, проекцией наиболее ранних геотермических градиентов в область очень высокой температуры (до $1000{ }^{\circ} \mathrm{C}$ ) на земной поверхности (Шкодзинский, 2018) и множеством других данных. Присутствие протопланетных дисков преимущественно у звезд с возрастом менее 10 млн лет указывает на то, что аккреция планет произошла за несколько миллионов лет, а не за миллиард, как это предполагал О. Ю. Шмидт.

Резкая химическая неравновесность мантийных пород с металлическим железом и распространение на Земле воды и углекислоты, а не продуктов их восстановления железом (Рингвуд, 1982) указывают, что силикатные и металли- 
ческие частицы никогда не были перемешаны в земных недрах и, следовательно, аккреция была гетерогенной. Ядро образовалось раньше мантии в результате объединения железных частиц в протопланетном диске под влиянием магнитных сил (Шкодзинский, 2018), поскольку при небольшом размере частиц эти силы были в миллиарды раз мощнее гравитационных, а магнитное поле Солнца, находившегося на эволюционной стадии Тау Тельца, было в это время в тысячи раз больше современного.

\section{ОШИБОЧНОСТЬ ГИПОТЕЗЫ МАГМООБРАЗОВАНИЯ ПУТЕМ ЧАСТИЧНОГО ПЛАВЛЕНИЯ}

Вследствие невысокой начальной температуры земных недр по гипотезе холодной аккреции причиной плавления при магмообразовании принимается разогрев вещества в результате распада радиоактивных элементов. Однако, ввиду низкого содержания этих элементов в мантии, в современном тепловом потоке доля этого тепла составляет менее 10 \% (Сорохтин, 2002). Сильный импактный разогрев при аккреции является главным источником глубинного тепла, что противоречит ведущей роли радиоактивного ра-

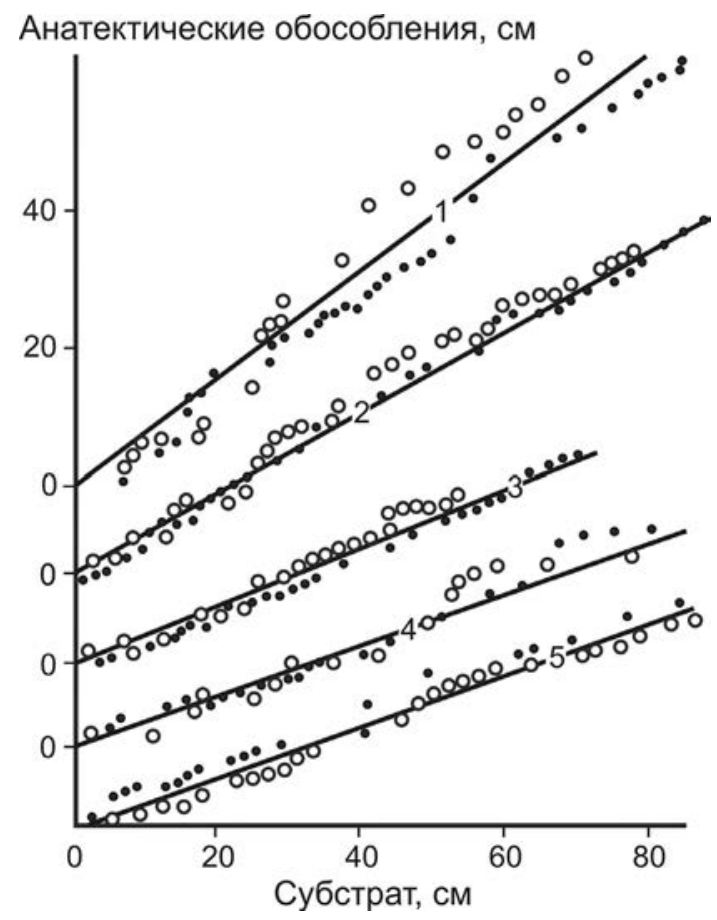

Puc. 1. Соотношение последовательных сумм мощностей анатектических обособлений и тел субстрата в биотит-гранатовых мигматитах р. Амедичи Алданского щита. Цифры на линиях - номера замеров (Шкодзинский, 1976)

Fig. 1. Correlation of successive sums of thicknesses of anatectic segregations and substrate bodies in biotite-garnet migmatites (Amedichi River, the Aldan shield) (Shkodzinskiy, 1976) зогрева в магмообразовании. Степень частичного плавления первичных ультраосновных пород принимается небольшой $(0.1$ \% для кимберлитовых магм и около $15 \%$ - для основных) (Грин, 1973), поскольку при большей степени состав выплавок не соответствует составу природных магм. Но при небольшой степени подплавления вязкость пород равна $10^{20}-10^{22}$ пуаз. Как показали расчеты, при такой огромной вязкости выплавки за всю историю Земли способны всплыть на доли сантиметра, что не может приводить к формированию магм (Шкодзинский, 1985). Это подтверждается отсутствием процессов разделения расплава и твердых фаз в перидотитах, подплавленных в экспериментах менее чем на 30 \% (Arndt, 1977).

Автохтонность выплавок полностью подтверждается результатами изучения мигматитов - единственного доступного наблюдению примера природного массового частичного плавления. Детальное исследование мигматитов Алданского щита и других регионов показало существование в них двух генетических разновидностей (Шкодзинский, 1976). В ортогнейсах жильный материал содержит больше гидроксилсодержащих минералов (биотита и роговой обманки) в темноцветной составляющей, чем в субстрате, и показывает на десятки градусов более низкую температуру образования. Это указывает на формирование жильного материала из остаточных расплавов ортогнейсов. В парагнейсах темноцветная составляющая анатектического жильного материала резко обогащена (до 90-100 \%) безводными минералами (гранатом, гиперстеном, кордиеритом), что свидетельствует о разложении гидроксилсодержащих минералов в результате растворения воды в расплаве при плавлении. Количество воды, выделявшейся из гидроксилсодержащих минералов, определяло степень анатектического плавления. Вода (по терминологии Д. С. Коржинского) является виртуальным инертным компонентом. Такое ее поведение опровергает широко распространенные в прошлом представления о метасоматическом генезисе мигматитов и гранитов. Анатектический жильный материал показывает более высокую температуру кристаллизации, чем субстрат.

Прямолинейность линий соотношения последовательных сумм мощностей тел анатектического жильного материала и субстрата (рис. 1) свидетельствует об отсутствии процессов отделения анатектического расплава в мигматитах даже при содержании около 40 \% (линия 1). Это обусловлено огромной вязкостью слабо подплавленных пород. Встречающиеся среди мигматитов относительно крупные тела гранитов не обогащены безводными темноцветными минералами, имеют другой состав и изотопный возраст, по срав- 
нению с анатектическим жильным материалом мигматитов, вследствие чего они не формировались из анатектических расплавов мигматитов.

\section{ОБРАЗОВАНИЕ МАГМ НА РАННЕЙ СТАДИИ ЭВОЛЮЦИИ ЗЕМЛИ}

Полученные доказательства горячей гетерогенной аккреции Земли приводят к принципиально новому решению проблемы генезиса магм. Плавление падавшего на железное ядро силикатного материала под влиянием огромного импактного тепловыделения обусловило возникновение глобального магматического океана на самой ранней стадии аккреции мантии (Шкодзинский, 2018). Его существование является причиной отсутствия на Земле пород древнее 3.8 млрд лет и кратеров завершавшей аккрецию гигантской метеоритной бомбардировки.

Малобарическая кристаллизация и фракционирование придонного слоя раннего еще малоглубинного магматического океана под влиянием роста нагрузки образующихся при аккреции его верхних частей привели к формированию огромного количества кислых и толеитовых остаточных расплавов при большой (более 97 \%) и меньшей (80-90%) степени кристаллизации первичных перидотитовых магм. Это объясняет очень широкое распространение на Земле пород такого состава и кислой кристаллической коры. Проблема генезиса кислых магм не имеет обоснованного решения с позиций господствующей гипотезы холодной аккреции. Это связано с тем, что для образования кислых выплавок из первичных ультраосновных пород необходимо давление менее 0.2 ГПа (Грин, 1973). Но при холодной аккреции на соответствующей этому давлению глубине менее 7-8 км никогда не могли существовать крупные участки с температурой более $900{ }^{\circ} \mathrm{C}$, необходимой для начала плавления ультраосновных пород. Многочисленным предположениям о выплавлении кислых магм из глубинных основных пород противоречат отсутствие признаков плавления основных кристаллических сланцев даже в самых высокотемпературных метаморфических комплексах, отсутствие кислых обособлений в многочисленных ксенолитах эклогитов из кимберлитов и самое раннее начало формирования кислых магматических пород (3.8 млрд лет назад) на Земле по изотопным данным (Балашов, 1985). Постепенное увеличение температуры и глубины магматического океана при аккреции обусловили эволюцию состава остаточных расплавов, возникавших при его придонном фракционировании, от кислых до основных и ультраосновных и образование идентичных им по составу слоев в магматическом океане (рис. 2). Его кумулаты сформировали ультраосновные породы мантии.

При горячем образовании Земли неизбежное укрупнение тел в протопланетном диске, обусловившее сокращение удельных потерь импактного тепла на излучение и рост силы гравитационного притяжения увеличивавшейся Земли, приводило к возрастанию температуры от ранних стадий аккреции мантии к поздним. Величина этого возрастания различными исследователями оценивается в 800-3000 ${ }^{\circ} \mathrm{C}$ (Шкодзинский, 2018). Из этого следует вывод о том, что на ранней Земле температура в мантии увеличивалась снизу вверх; в ней существовал обратный современному геотермический градиент, что предполагали некоторые исследователи (Сафронов, 1987; Сорохтин, 2002). Следовательно, в это время не было всемантийной конвекции и отсутствовали современные геодинамические обстановки. Они появились в конце протерозоя после прогрева мантии изначально очень горячим ядром. Значительно меньшие по размеру ядра на других планетах земной группы не смогли прогреть их мантии. Это объясняет отсутствие на них явных признаков проявлений плитной тектоники и современного магматизма.

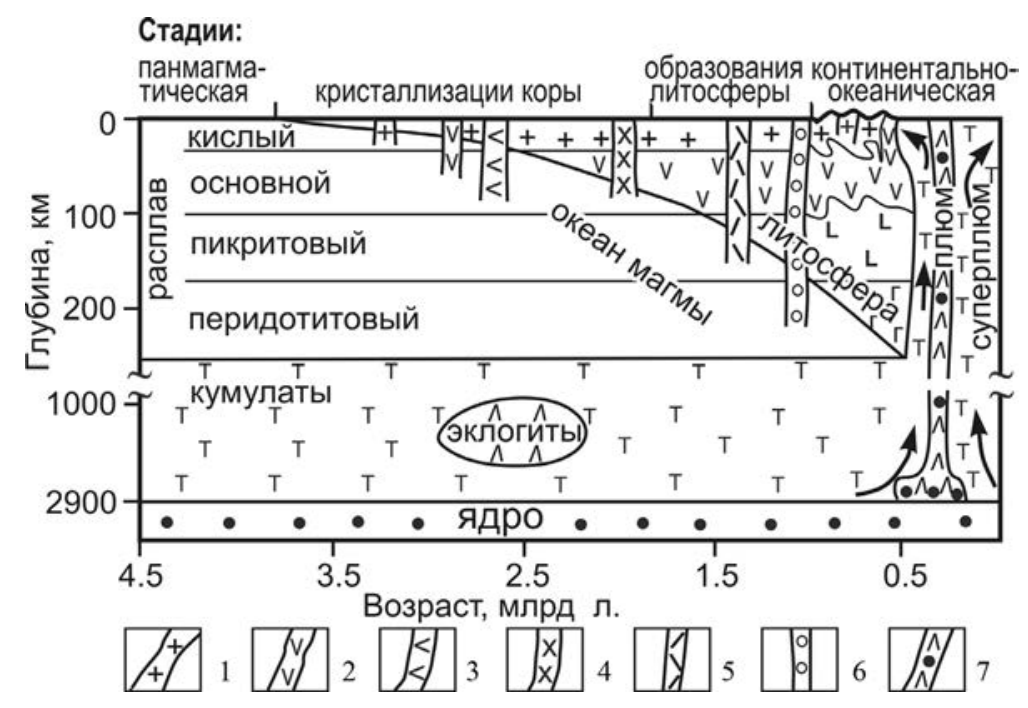

Рис. 2. Схема образования различных геодинамических обстановок и магм: 1 - кислых, 2 - основных, 3 - анортозитовых, 4 щелочно-основных, 5 - щелочно-ультраосновных карбонатитсодержащих, 6 - кимберлитовых, 7 - океанических и траппов, иногда содержащих ксенолиты ядра

Fig. 2. Scheme of various geodynamic settings and magmas formation: 1 - acidic, 2 - basic, 3 - anorthositic, 4 - alkaline-basic, 5 - alkaline-ultrabasic with carbonatites, 6 - kimberlitic, 7 - oceanic and trap, sometimes with core xenoliths 
Расчеты показали, что плотность возникавших в результате остывания магматического океана кислых и средних по составу пород

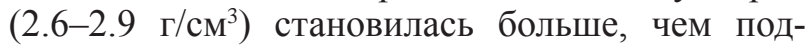
стилавших не закристаллизованных расплавов

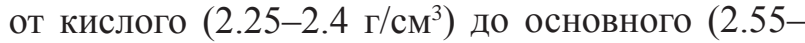
$2.76 \Gamma / \mathrm{cm}^{3}$ ) и частично ультраосновного (более $2.76 \Gamma / \mathrm{cm}^{3}$ ) состава (Шкодзинский, 2018). Это приводило к периодическому погружению затвердевших пород, начавших на них формироваться осадков и к всплыванию на их место подстилавших магм от кислого до ультраосновного состава. Такое явление объясняет широко распространенное в раннедокембрийских кристаллических комплексах чередование ортогнейсов, парагнейсов и кристаллических сланцев. Вследствие большого давления плотной газовопаровой оболочки излияния магм не сопровождались взрывами в результате быстрого выделения газов, что объясняет отсутствие в кристаллических комплексах метаморфизованных вулканических брекчий. Большая длительность остывания огромного объема глобального океана магмы обусловила огромную продолжительность формирования раннедокембрийских кристаллических комплексов, достигающую на Алданском щите более миллиарда лет.

Идентичность гистограмм распределения температур кристаллизации гиперстенсодержащих и безгиперстеновых гнейсов (Шкодзинский,
2018) свидетельствует, что образование этих пород обусловлено не различной температурой их гипотетического метаморфизма, как принято считать, а различным содержанием воды в исходных магмах. Это подтверждается широко распространенным переслаиванием гиперстеновых и безгиперстеновых гнейсов и отсутствием случаев развития гиперстенсодержащих пород по безгиперстеновым (Салоп, 1982).

Магматический генезис большинства пород раннедокембрийских кристаллических комплексов объясняет одинаковую во всех регионах высокую магматическую температуру их образования (800-850 $\left.{ }^{\circ} \mathrm{C}\right)$ (рис. 3), регрессивную последовательность минералообразования в них, отсутствие постепенных переходов в низкотемпературные комплексы и признаков существования мощных (десятки километров) перекрывающих толщ, с теплоизолирующим влиянием которых обычно связывают их гипотетический метаморфизм.

Таким образом, раннедокембрийские кристаллические комплексы и кислая кора являются не метаморфизованными вулканогенноосадочными толщами, а огромным длительно формировавшимся единым многофазным магматическим телом с ксенолитоподобными включениями осадочных пород. Каждая фаза формировала в нем преимущественно линзовидные тела над более ранними.

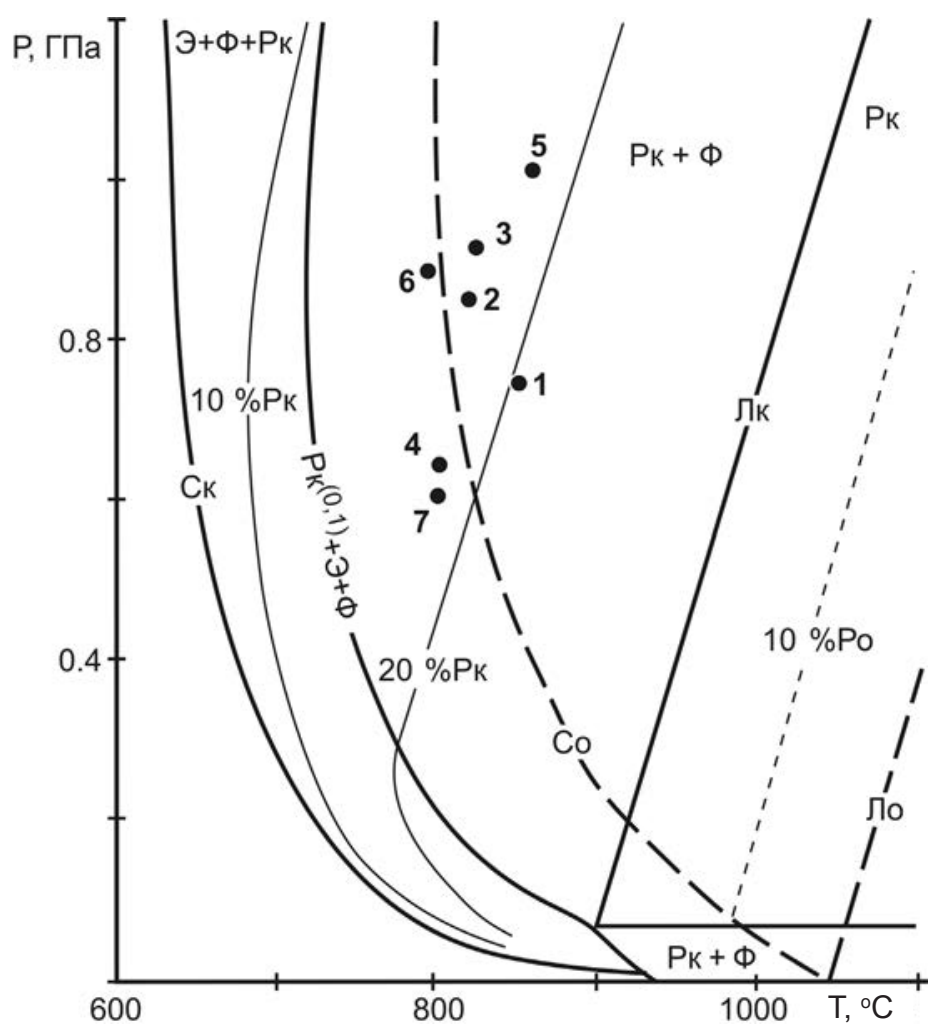

Puc. 3. Средние параметры образования кристаллических комплексов Алданского щита (1, среднее из 36 определений), Анабарского щита (2, 12 определений), Лапландского пояса $(3,11$ определений), Украинского щита (4, 4 определения), Антарктиды (5, 1 определение), Урала (6, 10 определений), Беломорья (7, 12 определений). По данным (Гранулитовые..., 2007). Лк и Ло, Ск и Со - соответственно ликвидусы и солидусы кислых и основных магм; Рк и Ро - расплавы соответственно кислые и основные; Ф - флюид; Э - минералы гранитов; $10 \%$ Рк и $10 \%$ Ро - содержания соответственно кислого и основного расплава; $\mathrm{P}^{(0.1)}$ кислый расплав с отношением количества $\mathrm{CO}_{2}$ к $\mathrm{H}_{2} \mathrm{O}$, равным 0.1 (Шкодзинский, 1985)

Fig. 3. Average parameters of formation of crystal complexes in the Aldan shield (1, average of 36 definitions), Anabar shield (2, 12 definitions), Lapland belt (3, 11 definitions), Ukrainian shield (4, 4 definitions), Antarctica (5, 1 definition), the Ural $(6,10$ definitions), the White sea (7, 12 definitions). After (Granulite..., 2007). Лк and Ло, Ск and Co - respectively, liquiduses and soliduses of acid and basic magmas; Рк and Po - melts, respectively, acid and basic; $\Phi$ - fluid; Э-granite minerals; $10 \%$ Рк and $10 \%$ Po content, respectively, acid and basic melt; $\mathrm{P \kappa}^{(0.1)}$ acid melt with the proportion of $\mathrm{CO}_{2}$ to $\mathrm{H}_{2} \mathrm{O}$ equal to 0.1 (Shkodzinskiy, 1985) 
Поздними тектоническими процессами оно было расчленено на тектонические блоки и комплексы. Раннедокембрийские ультраосновные и основные комплексы образовались из магм позднего магматического океана. Поэтому они обычно содержат повышенное количество расплавофильных компонентов, чем отличаются от фанерозойских океанических мафитов, которые возникли из расположенных в нижней мантии дифференциатов раннего магматического океана, бедного расплавофильными компонентами.

Отделение большого объема рудоносных эманаций из кислого слоя магматического океана привело к образованию многочисленных рудных месторождений преимущественно в зеленокаменных поясах. Огромный объем кислого слоя обусловил возникновение уникальных запасов этих месторождений. Например, суммарная мощность рудных пластов на железорудных месторождениях иногда составляет более километра. Максимальное содержание летучих компонентов в кислых магмах позволяет предполагать присутствие уникально крупных месторождений в участках наибольшей мощности кислой коры. Именно такая кора развита в районе уникального месторождения Витватерсранд, из которого извлечено около $40 \%$ всего золота, добытого за всю историю человечества. Подобные участки содержат повышенное количество зеленокаменных поясов, в пределах которых геофизические методы позволяют открыть новые уникальные месторождения под осадочным чехлом.

На поздних стадиях кристаллизации кислого слоя магматического океана в нем формировались лейкократовые остаточные кислые расплавы. Это является причиной широко распространенного образования в раннедокембрийских кристаллических комплексах - гранитных интрузий иногда лейкократового субщелочного состава (см. рис. 2). Последующая кристаллизация более глубинных среднего и основного по составу слоев обусловила образование и всплывание субщелочных и щелочных остаточных расплавов и формирование соответствующих по составу комплексов. Подъем богатых плагиоклазовыми кумулатами магм привел к образованию автономных анортозитов, также широко распространенных на древних щитах. После полного затвердевания верхних частей магматического океана внедрение их прекратилось, что объясняет ограниченный возрастной интервал образования автономных анортозитов и их значительную древность (2.8-1.1 млрд лет; Богатиков и др., 1987). Участие в их формировании среднего по составу слоя магматического океана является причиной преимущественно андезинового состава их плагиоклаза.
По экспериментальным данным кристаллизация мафических магм, содержащих во флюидной составляющей более 0.6 мольной доли углекислоты, приводит к образованию карбонатитовых остаточных расплавов при давлении менее 2.5 ГПа и кимберлитовых - при более высоком. Это объясняет формирование карбонатитов и кимберлитов на древних платформах. Кристаллизация магматического океана сверху вниз является причиной более древнего возраста карбонатитов по сравнению с кимберлитами - в среднем соответственно 688 и 236 млн лет (Шкодзинский, 2018). Раздвижение континентальной литосферы при образовании океанических областей является причиной отсутствия в них кимберлитов (правило Клиффорда). Таким образом, кристаллизация магматического океана объясняет генезис, состав и последовательность образования магматических пород на древних платформах.

Интенсивность геологических процессов в период от 2.2 до 1.2 млрд лет назад была самой низкой в истории Земли. Он получил название «мертвая земля» (Добрецов, 2011). Это объясняется тем, что к этому периоду глобальный магматический океан почти полностью остыл и затвердел, а процессы всемантийной конвекции еще не начались.

\section{ВОЗНИКНОВЕНИЕ МАГМ В ФАНЕРОЗОЙСКИХ ОКЕАНИЧЕСКИХ И СУБДУКЦИОННЫХ ОБСТАНОВКАХ}

Постепенный прогрев мантии изначально очень горячим ядром должен был привести к возникновению прямого геотермического градиента и мощной всемантийной конвекции. Резкое возрастание интенсивности тектонических процессов, начавшееся на рубеже 1.2 млрд лет назад, мощности формировавшихся осадков и молодой возраст дна современных океанов (менее 0.15 млрд лет; Салоп, 1982) указывают, что интенсивная конвекция началась в конце протерозоя. С позиций господствующей гипотезы возникновения ядра и мантии в результате опускания в ней железных частиц, эти геосферы должны были иметь почти одинаковую температуру, поэтому причина конвекции является непонятной. Высказывались самые экзотические предположения о ее природе - высоком содержании в ядре радиоактивных элементов, присутствии в нем антиматерии. Однако им противоречат результаты изучения железных метеоритов, являющихся обломками ядер мелких планет (Додд, 1986).

При горячей гетерогенной аккреции Земли ядро должно быть значительно горячее мантии, поскольку оно быстро формировалось с участием мощных магнитных сил. Это согласуется с геофизическими данными о большей температуре ядра (на 1-2 тыс. градусов; Bukowinskii, 
1999). При такой аккреции должны существовать два типа мантийных плюмов - очень крупные, преимущественно ультраосновные, и более мелкие - основные. Прогрев мантии ядром приводил к всплыванию ее горячих нижних частей после установления прямого геотермического градиента. Вследствие большого размера этих частей и небольшой разницы плотностей подогретых и не подогретых пород (сотые доли г/ $\mathrm{cm}^{3}$ ) возникали огромные суперплюмы. Преимущественно ультраосновной состав их вещества обусловил пониженную степень декомпрессионного плавления при подъеме и его значительную вязкость. Судя по вязкости астеносферы, она составляет около $10^{19}$ пуаз. Вследствие такой большой ее величины растекающееся под литосферой вещество суперплюмов оказывает на нее огромное динамическое воздействие. Оно приводит к ее раздвижению, возникновению океанических и субдукционных областей, дрейфу континентов и другим проявлениям тектоники литосферных плит. Эти суперплюмы являются, преимущественно, тектоногенерирующими.

Возникавшие при аккреции на дне магматического океана импактные кратеры заполнялись преимущественно основными придонными его расплавами, которые быстро компрессионно затвердевали и формировали крупные тела основных пород. Они имеют в среднем на $0.1-$

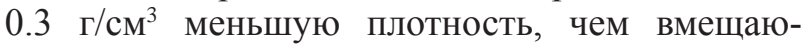
щие ультраосновные породы, поэтому и должны были всплывать после установления в мантии прямого геотермического градиента. То есть, кроме конвекции, связанной с подогревом мантийного вещества ядром, существует конвекция, обусловленная первичной неоднородностью состава мантии. Вследствие легкоплавкости вещество основных плюмов почти полностью переплавляется под влиянием мощной декомпрессии при подъеме и поэтому имеет в миллиарды раз меньшую вязкость (первые пуазы), чем ультраосновное вещество суперплюмов. По этой причине основные плюмы оказывают небольшое механическое воздействие на литосферу. Но преимущественно расплавленное состояние их вещества приводит к быстрому образованию больших объемов магматических пород. Это объясняет формирование, главным образом в фанерозое, менее чем за 1-2 млн лет гигантских полей траппов объемом в миллионы кубических километров. Такие плюмы являются преимущественно магмогенерирующими.

В траппах иногда присутствуют крупные тела (желваки, линзы) самородного железа, достигающие веса десятков тонн, и мелкозернистые железо-силикатные агрегаты, возникшие из остаточных расплавов с растворенным железом. Обычно отсутствие пространственной свя- зи с углеродсодержащими толщами противоречит иногда предполагаемому их образованию в результате ассимиляции этих толщ (Рябов и др., 1985). В 20 тыс. раз большая фугитивность кислорода при формировании мантийных пород, чем в случае химической равновесности их с железом (O’Neil, 1990), и другие данные указывают, что они не могли образоваться под влиянием подъема гипотетических потоков водорода. Содержание никеля (до 7 \%) и других примесей указывает на близость их по составу к низкотемпературным разновидностям железных метеоритов, являющихся обломками ядер мелких планет (Додд, 1986). Поэтому они должны быть ксенолитами внешних частей земного ядра, возникшими в наиболее ранних импактных кратерах на дне магматического океана (см. рис. 2).

Важным подтверждением их ксеногенного происхождения является резкое повышение железистости оливина в железных желваках и около них (от 42-48 \% фаялита до 62-66 \% в Айхальском силле) (Томшин и др., 2019). Следовательно, железо заимствовалось магмами из желваков, как должно быть при их ксеногенном генезисе. При образовании желваков путем восстановления оксидов железа магм оно должно перемещаться в противоположном направлении - из магм в желваки, а оливин в желваках был бы более магнезиальным. Присутствие в железосодержащих базитах магнетита, содержащего значительное количество высокоокисленного железа, также противоречит предполагаемому протеканию в них процессов восстановления. Очевидно, что при обычно принимаемом образовании основных магм путем обособления выплавок в верхней мантии эти магмы не могли выносить ксенолиты земного ядра. Поэтому присутствие таких ксенолитов является важным подтверждением предлагаемой модели магмообразования.

Связь движений литосферных плит с ультраосновными суперплюмами, а магматизма с основными плюмами объясняет существование магматизма «горячих точек», который обусловлен длительным подъемом стационарных небольших основных плюмов под движущимися плитами, что приводит к образованию цепочек магматических тел с уменьшающимся возрастом.

Вследствие гетерогенной аккреции и фракционирования при образовании Земли глобального магматического океана содержание накапливавшихся в расплавах компонентов увеличивается в мантии снизу вверх, поэтому возникшие в результате декомпрессионного переплавления ранних основных пород нижней мантии базальты срединно-океанических хребтов и траппов с ксенолитами земного ядра наиболее бедны ка- 
лием (в среднем менее $0.5 \%$ ) и другими расплавофильными компонентами, в то время как раннедокембрийские кристаллические сланцы намного богаче ими (до $2.7 \% \mathrm{~K}_{2} \mathrm{O}$ ), поскольку они возникали из вещества позднего магматического океана, в котором накапливались эти компоненты.

Как иллюстрируют линии подъема на Р-Т диаграмме (рис. 4), в природных гранитных магмах в глубинных условиях, под влиянием высокого давления, содержание твердых фаз составляет 60-80\%, поэтому из очагов зарождения магм начинает подниматься не расплав, а, преимущественно, твердофазные мигмы. При подъеме твердые фазы в них переплавляются под влиянием декомпрессии и фрикционного тепловыделения, что подтверждается гомогенизацией вещества гранито-гнейсовых диапиров при всплывании (Шкодзинский, 1976, 1985). На этом основании, кроме импактного тепловыделения, при аккреции мантии мощными магмообразующими факторами являются декомпрессия и фрикционное тепловыделение. Как известно, даже холодные приповерхностные породы иногда плавятся в зонах тектонических разломов с формированием псевдотахилитов. Расчеты показали, что характерные для зон субдукции стрессовые напряжения в 0.2-0.4 ГПа способны привести к образованию путем фрикционного переплавления наблюдаемых в этих зонах объемов магматических пород (Шкодзинский, 2020).

Большая эффективность фрикционного плавления подтверждается массовым современным вулканизмом на небольшом спутнике Юпитера Ио. На нем интенсивные деформации под влиянием переменного гравитационного притяжения то приближающихся, то удаляющихся при вращении Европы, Ганимеда и Юпитера приводят к извержению более 400 вулканов и образованию лавовых озер диаметром до 200 км. Фрикционное переплавление средних и кислых по составу пород литосферы под влиянием мощного давления раздвигающихся океанических плит является причиной постоянного образования большого количества магматических пород такого состава в субдукционных обстановках. Снижение интенсивности тектонических деформаций с удалением от океанов объясняет увеличение доли более низкотемпературных кислых магма- тических пород в этом направлении. Обычно повышенные значения начальных отношений изотопов стронция в субдукционных магматических породах (до 0.7226 в кислых вулканитах Перу) обусловлено большим накоплением радиогенного стронция за длительное время (более миллиарда лет) существования раннедокембрийских кислых пород в континентальной кристаллической коре до периода их фрикционного переплавления. Это, а также близость состава субдукционных кислых магматических пород к раннедокембрийским подтверждают фрикционное происхождение субдукционных магм. Такая близость обусловлена не образованием раннедокембрийских пород в этих обстановках, как обычно предполагается, а возникновением субдукционных магм путем переплавления кристаллической коры. Присутствие высококалиевых разновидностей в субдукционных основных породах, видимо, связа-

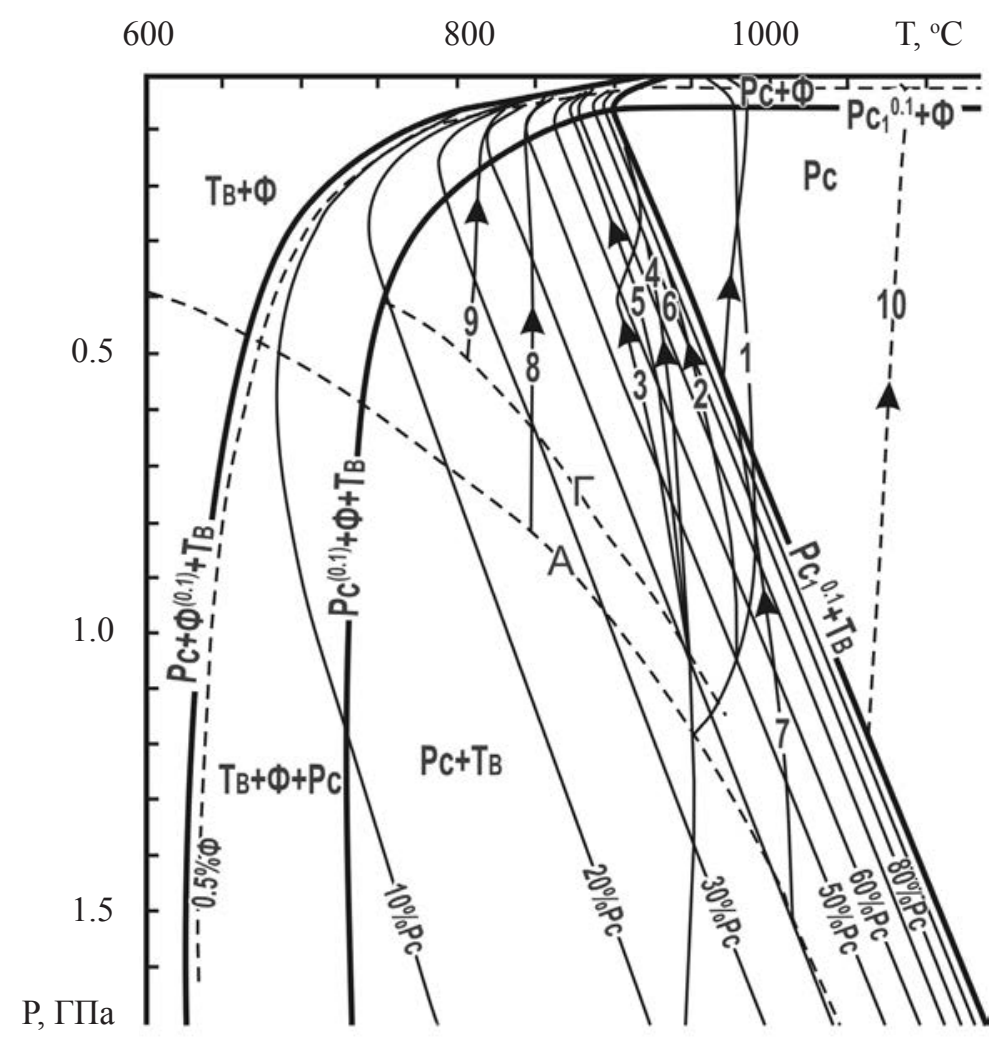

Puc. 4. Р-Т диаграмма фазового состава и эволюции (линии со стрелками) кислых магм с содержанием $1 \% \mathrm{H}_{2} \mathrm{O}$ и $0.1 \% \mathrm{CO}_{2}$. Рс - расплав, Ф - флюид, Э - кварц и полевые шпаты. 1-10 - линии эволюции магм при всплывании $(1,8-10)$ и тектоническом выжимании (2-7) (Шкодзинский, 1985). А - палеогеотерма Алданского щита, Г - более высокотемпературная геотерма

Fig. 4. P-T diagram of the phase composition and evolution (lines with arrows) of acid magmas with a content of $1 \% \mathrm{H}_{2} \mathrm{O}$ and $0.1 \%$ $\mathrm{CO}_{2}$. Pc - melt, F - fluid, Э- quartz and feldspars. 1-10 - lines of magma evolution at surfacing $(1,8-10)$ and tectonic squeezing $(2-7)$ A - paleogeotherm of the Aldan shield, $\Gamma$ - higher-temperature geotherm (Shkodzinskiy, 1985) 
но с протеканием процессов высокобарического фракционирования возникавших магм.

Очевидно, что в океанических областях тела основных пород в поднимающемся веществе суперплюмов должны плавиться под влиянием декомпрессии и фрикционного тепловыделения, формируя основные магмы, что объясняет массовое распространение базальтов на этих территориях. Подъем магм из каждого плавящегося тела основных пород в мантии должен был приводить к образованию на океаническом дне поднятий и островов. Их обилие в океанах указывает на существование большого количества линз основных пород в мантии. Смена во времени на островах толеитового магматизма щелочным свидетельствует о процессах фракционирования магм на глубинных этапах подъема.

\section{ВЫВОДЫ}

Таким образом, учет доказательств горячей гетерогенной аккреции позволил разработать принципиально новую модель образования магм, в свете которой существуют четыре механизма их формирования:

1) путем подъема расплавов из магматического океана (первичные и первично-остаточные магмы древних платформ);

2) в результате декомпрессионного переплавления затвердевших дифференциатов этого океана во всплывавших плюмах (декомпрессионноплюмовые магмы траппов, рифтов, океанических областей);

3) путем фрикционного переплавления этих дифференциатов в зонах интенсивных тектонических деформаций (фрикционные магмы субдукционных, коллизионных и частично океанических областей);

4) в результате фракционирования в магматических камерах в условиях различной глубинности (вторично-остаточные магмы поздних фаз магматических комплексов различных обстановок).

Главной причиной разнообразия породных комплексов на Земле является магматическое фракционирование, а не отделение выплавок из слабо подплавленных пород, что обусловлено в миллиарды раз меньшей вязкостью магм по сравнению с этими породами.

\section{ЛИТЕРАТУРА}

Балашов Ю. А. Изотопно-геохимическая эволюция мантии и коры Земли. Москва : Наука, 1985. 221 с.

Богатиков О. А., Богданова С. В., Борсук А. М., Бубнов С. Н., Дмитриев Ю. И., Коваленко В. И.,
Кононова В. А., Красивская И. С., Лазько Е. Е., ЛобачЖученко С. Б., Марков М. С., Павлов В. А., Рябчиков И. Д., Симон А. К., Цветков А. А., Чесноков С. В., Шарков Е. В., Ярмолюк В. В., Яшина Р. М. Магматические горные породы. Эволюция магматизма в истории Земли. Москва : Наука, 1987. 439 с.

Гранулитовые комплексы в геологическом развитии докембрия и фанерозоя : Материалы II Российской конференции по проблемам геологии и геодинамики докембрия (Санкт-Петербург, 22-24 октября 2007 г.). Санкт-Петербург, 2007. 407 с.

Грин Д. Х. Состав базальтовых магм как критерий их возникновения при вулканизме / ред. Э. Буллард, Дж. Канн, Д. Метьюз // Петрология изверженных и метаморфических пород дна океана. Москва : Мир, 1973. C. $242-261$.

Добрецов Н. Л. Основы тектоники и геодинамики. Новосибирск : Изд-во НГУ, 2011. 492 с.

Додд Р. Т. Метеориты - петрология и геохимия. Москва : Мир, 1986. 382 с.

Рингвуд А. E. Происхождение Земли и Луны. Москва : Недра, 1982. $294 \mathrm{c}$.

Рябов В. В., Павлов А. Л., Лопатин Г. Г. Самородное железо сибирских траппов. Новосибирск : Наука, $1985.170 \mathrm{c}$.

Салоп Л. Н. Геологическое развитие Земли в докембрии. Ленинград : Недра, 1982. 334 с.

Сарронов В. С. Происхождение Земли. Москва : Знание, 1987. $46 \mathrm{c.}$

Сорохтин О. Г. Развитие Земли. Москва : Изд-во МГУ, 2002. $506 \mathrm{c}$.

Томшин М. Д., Салихов Р. Ф., Матушикин А. И., Маковчук И. В., Копылова А. Г., Васильева А. Е. Самородное железо в долеритах Айхальского силла (первая находка в Якутии) // Природные ресурсы Арктики и Субарктики. 2019. № 3. С. 72-79.

Шкодзинский В. С. Глобальная петрология по современным данным о горячей гетерогенной аккреции Земли. Якутск : Изд-во СВФУ, 2018. 274 с.

Шкодзинский B. С. Проблемы физико-химической петрологии и генезиса мигматитов (на примере Алданского щита). Новосибирск : Наука, 1976. $224 \mathrm{c}$

Шкодзинский В. С. Происхождение магм как результат горячей аккреции Земли // Вестник геонаук ИГ Коми НЦ. 2020. № 2. С. 6-14.

Шкодзинский В. С. Фазовая эволюция магм и петрогенезис. Москва : Наука, 1985. 232 с.

Шмидт О. Ю. Происхождение Земли и планет. Москва : Изд-во АН СССР, 1962. 132 с.

Arndt N. T. The separation of magmas from partially molten peridotite // Carnegie Institution Washington Yearbook. 1977. Vol. 76. P. 424-428.

Bukowinskii M. S. Taking the core temperature // Nature. 1999. No. 6752. P. 432-433.

O'Neil H. S. Oxygen fugacity and siderophile elements in the Earth's mantle: implications for the origin of the Earth // Meteoritics. 1990. No. 25 (4). P. 395. 


\title{
GENESIS OF MAGMAS ACCORDING TO DATA ON HOT HETEROGENEOUS ACCRETION OF THE EARTH
}

\author{
V.S. Shkodzinskiy \\ Diamond and Precious Metal Geology Institute, SB RAS, Yakutsk
}

\begin{abstract}
The obtained numerous proofs of hot heterogeneous accretion of the Earth lead to a fundamentally new solution of the magma genesis problem. According to these data, in the course of the silicate mantle accretion, the global magmatic ocean emerged under the impact heat emission. Its bottom part crystallized and fractionated as a result of the pressure increase of the upper parts being formed. Cumulates formed the ultrabasic mantle; residual melts, the magmatic ocean. The increase in ocean temperature and depth caused the evolution of bottom residual melts from acidic to ultrabasic, the appearance of corresponding layers in the ocean, and the reverse geothermal gradient in the mantle. The top-down cooling and crystallization of the ocean, 3.8 billion years ago, Early Precambrian crystal complexes, acidic crust, and the lithosphere of ancient platforms were formed. The separation of residual melts from various layers determined the evolution of magmatism from acidic to alkaline-ultramafic and kimberlite. Heating of the mantle by a high-temperature core resulted in the appearance of a direct geothermal gradient at the end of the Proterozoic, convection in the mantle, and modern geodynamic environments. In the latter, magmas are formed by the frictional and decompression remelting of the magmatic ocean differentiates.
\end{abstract}

Keywords: magma genesis, magmatic ocean, frictional and decompression melting.

\section{REFERENCES}

Arndt, N. T., 1997. The Separation of Magmas from Partially Molten Peridotite, Carnegie Institution Washington Yearbook. 76, 424-428.

Balashov, Ju. A., 1985. Izotope-Gechemical Evolution of the Earth's Mantle and Crust. Moscow, Nauka [In Russan].

Bogatikov, O. A., Bogdanova, S. V., BorsukA. L., Bubnov, S. N., Dmitriyev, Yu. I., Kovalenko, V. I., Kononova, V. A., Krasivskaya, I. S., Lazko, Ye. Ye., Lobach-Zhuchenko, S. B., Markov, M. S., Pavlov, V. A., Ryabchikov, I. D., Simon, A. K., Tsvetkov, A. A., Chesnokov, S. V., Sharkov, Ye. V., Yarmolyuk, V. V., Yashina, R. M., 1987. Magmatic Rocks. Vol. 6. Evolution of Magmatism in the History of the Earth. Moscow, Nauka [In Russian].

Bukowinskii, M. S., 1999. Taking the Core Temperature, Nature. 6752, 432-433, 23.

Dobretsov, N. L., 2011. Fundamentals of Tectonics and Geodynamics. Novosibirsk, Novosibirsk State University [In Russian].

Dodd, R. T., 1968. Meteorites: Petrology and Geochemistry. Moscow, Mir [In Russian].

Granulite Complexes in the Precambrian and Phanerozoic Geological Evolution, 2007. Materials of the 2nd Russian Conference on Precambrian Geology and Geodynamic (Saint-Petersburg, October 22-24, 2007). SaintPetersburg [In Russian].

Green, D. H., 1973. Composition of Basalt Magmas as a Criterion for Their Origin at Volcanism, Eds. E. Bullard, J. Cann, D. Mattews. Petrology of Igneous and Metamorphic Rocks of the Ocean Floor. Moscow, Mir. 242-261 [In Russian].

O'Neil, H. S., 1990. Oxygen Fugacity and Siderophile Elements in the Earth's Mantle: Implications for the Origin of the Earth, Metioritics. 25 (4), 395.
Ringwood, A. E., 1982. Origin of the Earth and the Moon. Moscow, Nedra [In Russian]. Ryabov, V. V., Pavlov, A. L., Lopatin, G. G., 1985. Native Iron of Siberian Traps. Novosibirsk, Nauka [In Russian].

Salop, L. N., 1982. Geological Development of the Earth in the Precambrian. Leningrad, Nedra [In Russian]. Safronov, V. S., 1987. Origin of the Earth. Moscow, Nedra [In Russian].

Schmidt, O. Y., 1982. Origin of the Earth and the Planets. Moscow, AN USSR [In Russian].

Shkodzinskiy, V. S., 1976. Problems of PhysicalChemical Petrology and Genesis of Migmatites (Exemplified by the Aldan Shield). Novosibirsk, Nauka [In Russian].

Shkodzinskiy, V. S., 1985. Phase Evolution of Magmas and Petrogenesis. Moscow, Nauka [In Russian].

Shkodzinskiy, V. S., 2018. Global Petrology by the Current Data on Hot Heterogeneous Accretion of the Earth. Yakutsk, North-Eastern Federal University in Yakutsk [In Russian].

Shkodzinskiy, V. S., 2020. Magma Genesis as Result of Hot Accrertion of the Earth, Vestnik of the Institute of Geology of the Komi Science Center of the Ural Branch of the Russian Academy of Sciences. 2, 6-14 [In Russian].

Sorokhtin, O. G., 2002. Evolution of the Earth in Precambrian. Moscow, Lomonosov Moscow State University [In Russian].

Tomshin, M. D., Salikhov, R. F., Makovchuk, I. V., Kopylova, A. G., Vasilyeva, A. E., 2019. Native Iron in Dolerites of the Aikhal Sill (First Find in Yakutia), Arctic and Subarctic Natural Resources. 3, 72-79 [In Russian]. 